\title{
Microbiota's response to natural-anthropogenic changes in moisture in a trans-zonal aspect: A case study for the south part of East European Plain
}

\author{
Fedor Nikolaevich Lisetskii* and Denis Borisovich Vladimirov \\ Belgorod National Research University, Institute of Earth Sciences, Belgorod, Russia
}

\begin{abstract}
In semi-arid areas, irrigation changes not only the chemically and physical properties of soil, but also the activity of microbiota. We undertook a study of algal flora and enzyme in the trans-zonal range: from the foreststeppe to the dry-steppe, which is lacking precipitation and where surface irrigation is widely used. The aims of the study were to reveal the activity of five soil enzymes and abundance of algae under the influence of irrigation on the south of the East European Plain (Ukraine, Moldova) and to determine the contribution of the biological factor to the increase of wind and water erosion resistance of irrigated soils. The activity of algae during irrigation had the most favourable conditions in the fall (3-42 thousand / $g$ of soil), which was facilitated by optimal soil moisture (2124\%). Soils in irrigated conditions in spring and summer featured a higher content of dehydrogenase (on $41 \%)$ and polyphenol oxidase (on 34\%) compared to non-irrigated soils. Irrigated soils also differed by higher urease content (on 17\%) than on non-irrigated soils and in spring these differences were up to 50\%. The explanation for this phenomenon is associated with the action of irrigation in respect of increasing the role of humus coagulation of elementary soil particles, the increase in the proportion of particles $<0.001 \mathrm{~mm}$ as products of weathering and the increase of bacterial origin cement.
\end{abstract}

Keywords: Algal flora, enzymes, erosion resistance, irrigated soils, semi-arid landscapes

\section{Introduction}

Microorganisms and microbiological processes play an important role in the development of soil fertility and in plant nutrition (Orudzheva, 2011; Kuzyakov and Blagodatskaya, 2015; Van Wyk et al., 2017), and also largely determine ecological functions in soils (Dobrovol'skaya et al., 2015; Zhang et al., 2016; Siebert et al., 2019). Soil biological health is one of the best diagnostic indicators for soil fertility (Ullah et al., 2014). Growth promoting bacteria can help the plant to function normally by suppressing the pathogen (Akhtar et al., 2018).

Irrigated soils are characterized by a special irrigationcontrast type of water regime, which changes the physical and chemical properties and material composition of soils, the quantity and quality of organic matter and the regime of the level and salinity of groundwater. It was revealed that content of organic carbon (C), bacterial biomass and structural community diversity (Entry et al., 2008; Moreno et al., 2019), and also the activity of microflora (Azotobacter, Ammonifiers and Nitrifiers) changes under the influence of irrigation reclamation (Rietz and Haynes, 2003; Guo et al., 2017).
The centuries-long experience of irrigation farming has shown that obtaining stable high yields of agricultural crops for a long time is possible only with the preservation of soil fertility. Objective monitoring of irrigated lands by using satellite imagery shows that the areas of saline soils tended to grow continuously (Savin et al., 2014). The different irrigation water salinity will form significant differences of soil bacterial community (Guo et al., 2019). The analysis of many years of irrigation in Ukraine (the beginning of the development of irrigation after 1945, but the intensive construction of systems since 1966) showed that the increase in the yield of grain crops under irrigation was lower than expected (Popelnitskaya and Trigub, 2016).

Zonal and regional diversity of soils and climate dynamics were not adequately considered when designing irrigation systems. Areas of irrigated agriculture are increasing. These soils change to various extent under the influence of irrigation. In the trans-zonal cut (from module, ordinary and southern Chernozems to dark brown soils), irrigated areas are increasing on average four times. The microbiological activity of soils in the arable layer changes under the influence of irrigation more intensively than the

\footnotetext{
*Email: liset@bsu.edu.ru
} 
humus state (Shvebs et al., 1988; Prikhod'ko, 2008; Tan et al., 2018).

It should be noted that river waters used for irrigation, bring in microorganisms into the soils (heterotrophs, ammonifiers, nitrifiers, etc.). Earlier it was noted (Prikhod'ko, 2008) that with ordinary Chernozems irrigation, due to insufficient fertilization and increased microbiological activity, there is a loss of humus with a small yield gain. However, irrigation of southern Chernozems and dark brown soils can provide a grain crop in 1.5-3 times and a grass yield in 2-3 times return from water impounding. The situation with carbonate Chernozems distinguished in Moldova as an independent soil subtype, is similar to a certain extent southern Chernozems (Lisetskii et al., 2013).

Due to the frequent drought, the soils of the semi-arid regions contain soil microbial communities being sensitive to seasonal and year-to-year moisture variations (Preece et al., 2019). The development of bacterial microflora and fungi is stimulated by high humidity in the irrigated soils of denitrifiers decreases, the number of Azotobacter noticeably increases (Rietz and Haynes, 2003; Guo et al., 2017; Lisetskii et al., 2018).

The aims of the study were to reveal the peculiarities of the activity of five soil enzymes and abundance of algal flora under the influence of irrigation in the trans-zonal section of the East European Plain - from forest-steppe to dry steppe and to determine the contribution of the biological factor to the increase of wind and water erosion resistance of irrigated soils.

\section{Materials and Methods}

\section{Research area}

Within the limits of the East European Plain foreststeppe zone, this is the first natural area (when moving from north to south) where evaporation is greater than the annual amount of precipitation, and moisture deficit increases in the zone, which leads to the development of land irrigation (Lisetskii et al., 2010). The main climatic parameters for the five regions of the study are presented in Table 1. The

Table 1: Climatic conditions regions of research

\begin{tabular}{llllllll}
\hline Region & \multicolumn{2}{l}{ Coordinates } & m a.s.l. & $\mathbf{T}^{\mathbf{a}}\left({ }^{\circ} \mathbf{C}\right)$ & $\mathbf{P}^{\mathbf{b}}(\mathbf{m m})$ & $\Delta \mathbf{P}^{\mathbf{c}}(\mathbf{m m})$ & $\mathbf{Q}^{\mathbf{d}}\left(\mathbf{M J} /\left(\mathbf{m}^{\mathbf{2}} \cdot \mathbf{y e a r}\right)\right.$ \\
\cline { 2 - 5 } & lat. ${ }^{\circ} \mathbf{N}$ & long. ${ }^{\circ} \mathbf{E}$ & & & & & 1132 \\
\hline A & 47.94 & 29.62 & 123 & 8.6 & 562 & 51 & 1090 \\
B & 47.00 & 30.27 & 120 & 9.4 & 504 & 40 & 1102 \\
C & 46.64 & 29.41 & 32 & 10.3 & 492 & 42 & 1037 \\
D & 46.30 & 30.65 & 26 & 10.5 & 449 & 22 & 1006 \\
E & 46.66 & 32.62 & 51 & 10.0 & 439 & 25 & \\
\hline
\end{tabular}

${ }^{\mathrm{a}} \mathrm{T}$, average annual air temperature; ${ }^{\mathrm{b}} \mathrm{P}$, average precipitation per year; ${ }^{\mathrm{c}} \Delta \mathrm{P}$, the difference in precipitation between the dry and rainy month; ${ }^{\mathrm{d}} \mathrm{Q}$, the energy costs of soil formation.

(Filip et al., 2000; Matei et al., 2011; Guo et al., 2014). Studies of the soil microbial community changes under the influence of irrigation have been carried out in many semiarid areas (Chen et al., 2017; Goenster et al., 2017; Azarbad et al., 2018). Less work is devoted to the study of enzyme activity in irrigated soils (Li et al., 2017; Liang et al., 2018; Moreno et al., 2019). One of the most widely used methods for assessing the intensity of soil-biological processes is the determination of enzymatic activity, which depends on the physical, chemical properties of soil, the nutrient content, the $\mathrm{pH}$ level, salinity, carbonate content, etc.

Previous studies (Shvebs et al., 1988; Bulygin and Lisetskiy, 1992) have shown that with steppe soil irrigation, the increase in water resistance of the aggregates and soil loss tolerance is due not only to an increase in soil microaggregation, but also to more intensive microbiological activity. Irrigation is a strong factor of pedogenesis, which changes the number, intensity and duration of microbiological activity; in particular, the number of ammonifiers, nitrifiers increases and the number coordinates of study plots are given in the WGS 84 global coordinate system.

Region A. Ukraine. Balta region. Southern foreststeppe. Chernozem module, heavy loam (Luvic Chernozem). The thickness of the humus horizon is $85 \mathrm{~cm}$. The content of Corg in the topsoil was 3.01\%. $\mathrm{pH}\left(\mathrm{H}_{2} \mathrm{O}\right)$ is 6.5 .

Region B. Ukraine. Ivanovka region. Medium-steppe subzone. Chernozem ordinary, little thickness, light loam, weakly eroded (Calcic Chernozem). Humus horizon thickness is $55 \mathrm{~cm}$. Corg is $1.74 \%$.

Region C. Moldova. Kaushany (Căuşeni) region. Medium-steppe subzone. Kaushany irrigation array. The design area of irrigation was 41.9 thousand ha; 6.4 thousand ha of irrigated areas were commissioned. The source of irrigation is the water of the Dniester River.

C/1. Carbonate, heavy loam Chernozem. Humus horizon thickness is $90 \mathrm{~cm}$. Corg is $1.68 \%$. 
$\mathrm{C} / 2$. Carbonate, weakly eroded, heavy loam Chernozem. Humus horizon thickness is $62 \mathrm{~cm}$. Corg is $1.22 \%$.

Region D. Ukraine. Ovidiopol region. Medium-steppe subzone. Southern heavy loam Chernozem. Humus horizon thickness is $55 \mathrm{~cm}$. Corg is $1.79 \%$. Lower Dniester irrigation system (it was built in 1964). The irrigation area exceeds 37 thousand ha. Groundwater occurs at a depth of $2-5 \mathrm{~m}$. The source of irrigation is the water of the Dniester River.

Region E. Ukraine. Kherson region. South-steppe (drysteppe) subzone. Dark brown soil, alkaline, heavy loam (Kastanozems). The humus horizon thickness is $35 \mathrm{~cm}$. Corg is $1.27 \%$. $\mathrm{pH}(\mathrm{KCl})$ is 7.4-7.6. Experimental field of irrigated agriculture. The source of irrigation is the water of the Dnieper River.

Soil properties, which have already changed so far under the influence of irrigation, have resulted from continuous irrigation engineering modernization to some extent. Until the 1960s, irrigation systems used surface furrow irrigation or open network sprinkling (annual ditches). The second stage (1960-1970) meant to construct channels from reinforced concrete trays and to use the tube network to supply water into portable pipelines for sprinkling machines. The third stage (1970-1990) is to construct closed irrigation systems using high-pressure wide-coverage sprinkler equipment of frontal and circular action. Currently, all large areas are occupied by drip irrigation (Romashchenko et al., 2016), which has significantly reduced water overheads and its excessive impact on soil processes.

\section{Soil analysis}

To calculate the energy costs of soil formation in a space point $\left(\mathrm{Q}, \mathrm{MJ} /\left(\mathrm{m}^{2}\right.\right.$.year $\left.)\right)$, one may use the results of the mean annual observations made by weather stations concerning such parameters as the annual amount of precipitation and the radiation balance value (Table 1). When we introduced the author's formula (Volobuev, 1959) the multipliers converting the radiation balance values in the international system of unit measurement, the calculation formula for $\mathrm{Q}, \mathrm{MJ} /\left(\mathrm{m}^{2}\right.$.year) value has been modified into the following form:

$Q=R \cdot e^{\left[-1,28 \frac{R^{0,73}}{P}\right)}$

Where $\mathrm{R}$ is the radiation balance, $\mathrm{MJ} /\left(\mathrm{m}^{2} \cdot\right.$ year $), \mathrm{P}$ is the annual rainfall amount, $\mathrm{mm}$.

In the regions $\mathrm{C}(\mathrm{C} / 1$ and $\mathrm{C} / 2), \mathrm{D}$ and $\mathrm{E}$, pairs of neighbouring sites were chosen that were under irrigation and similar conditions rain-fed farming (boghara). Soils on these plots were identified as objects for soil and microbiological research.

The determination of organic carbon (Corg) in the soil was performed by oxidation of the organic substance with a solution $\mathrm{K}_{2} \mathrm{Cr}_{2} \mathrm{O}_{7}$ in sulphuric acid until the formation of carbon dioxide (Arinushkina, 1970). The structural composition was evaluated by dry sieving (three replicates). The water-stable aggregates were evaluated by wet sieving (into six size fractions, from 5 to $<0.25 \mathrm{~mm}$ ). Resistance of soil structure to deflation (wind erosion) is determined by a content of structural aggregate of $>1 \mathrm{~mm}$ (in Table denoted by DEFL). This is one of the indicators of soil resistance to wind erosion. Experiments on artificial sprinkling were carried out within three periods. The method of artificial sprinkling the runoff sites of size $1 \mathrm{~m}^{2}$ using a drip sprinkler made it possible to determine the turbidity of the stream $\left(\rho_{0}\right.$, $\mathrm{g} / \mathrm{l})$ and the absolute value of washability $\left(\mathrm{R}_{0}, \mathrm{~g} / \mathrm{c} \cdot \mathrm{m}\right)$ for carbonate non-eroded and eroded chernozems for irrigation and rain-fed agriculture in region $\mathrm{C}$ (Moldova). It is advisable to consider the parameters $\rho_{0}$ and $\mathrm{R}_{0}$ separately, since the calculation of $\mathrm{R}_{0}$ additionally takes into account infiltration, which is essential for long-irrigated soils.

\section{Microbial methods}

The selection of soil samples was carried out in the dynamics (spring - summer - autumn) from the arable layer of soil $(0-20 \mathrm{~cm})$, and for research algal flora from a layer of $0-2 \mathrm{~cm}$. Each assay was compiled as a mixture of five individual samples, and of 10-15 samples for algal flora. Algae abundance (thousand per $\mathrm{g}$ of absolutely dry soil) was determined by luminescent microscopy in fresh soil samples $(0-2 \mathrm{~cm})$ and, after samples incubation under optimal hydropower conditions according to the Shtina-Pankratova (Bab'eva and Zenova, 1989). The activity of the five soil enzymes (dihydrogenase, phosphatase, invertase, urease, polyphenol oxidase) was determined according to the methods adopted in soil enzymology (Khaziev, 1976). The method of polyphenol oxidase activity determination was based on measuring the oxidation rate of soil-added polyphenols followed by purpurogallin calculation, using the colorimetric method. The soil activity dihydrogenase was determined with the use of tetrazolium salt $(2,3,5-$ triphenyltetrazolium chloride) followed by reducing into formazan compounds (triphenylphosphate) which was measured colorimetrically. The method for soil invertase activity determination was based on quantitative assessment of reducing sugars according to Bertrand. The urease activity was determined through the measurement of nonhydrolyzed urea amount. We calculated the content of phosphatase with the use of quantitative assessment of 
inorganic phosphorus, which was formed in the course of splitting of organic phosphorus compounds. Scales by D.G. Zvyagintsev (1980) were used to evaluate the studied soils by the degree of enzyme enrichment.

\section{Results}

\section{Trans-zone change in pedogenesis conditions}

Along the transect from the northwest to the southeast (the distance from the research area $A$ to $E$ is $250 \mathrm{~km}$ ), the average annual precipitation decreases by $123 \mathrm{~mm}$ with increasing heat supply (Table 1). The trans-zonal change in pedogenesis conditions in terms of heat and moisture reflects the energy costs of soil formation: The Q value (by (1)) at the northern and southern borders of natural zones decreases by $126 \mathrm{MJ} /\left(\mathrm{m}^{2} \cdot\right.$ year$)$. In a trans-zonal aspect (objects in the forest-steppe and the dry steppe), the difference in precipitation between the dry and rainy month reaches two or more times. In addition, spring droughts occur in the southern and dry steppe with a probability of $40 \%$.
It is important to note that irrigation changes the hydrothermal regime of the soil and due to the additional moisture, the increase in energy costs of soil formation (Q) can reach from $800 \mathrm{MJ} /\left(\mathrm{m}^{2} \cdot\right.$ year) (Chernozems) to 1200 $\mathrm{MJ} /\left(\mathrm{m}^{2} \cdot\right.$ year) (Kastanozems).

The main physical and chemical parameters of the studied soils are presented above (Lisetskii et al., 2018). The average Corg content decreases from the further north Chernozems subtypes to the southward subtypes and Dark brown soils from $1.8 \%$ to $1.2 \%$, respectively. Our longterm studies of the results of intense black soil irrigation have confirmed the conclusions made by other researchers that there are significant changes in soils' salt composition, basic properties and fertility. The irrigation effect is most commonly embodied in the accumulation of sodium and magnesium ions both in soil solutions and soil adsorption complex as well as in increased alkalinity, the development of solonetz-forming process and higher content of labile humus in the black soil-plowing layer.

Table 2: Soil moisture $(\%)$ in a layer of $0-20 \mathrm{~mm}$ seasonally

\begin{tabular}{ccccc}
\hline Soil number & Spring & Summer & Autumn & Mean \\
\hline A & 30.73 & 26.24 & 24.73 & $27.23 \pm 1.8$ \\
B & 24.53 & 22.61 & 24.16 & $23.77 \pm 0.6$ \\
C1b & 21.25 & 12.09 & 21.65 & $18.33 \pm 3.1$ \\
C1ir & 23.28 & 18.78 & 23.05 & $21.70 \pm 1.5$ \\
C2b & 18.51 & 20.50 & 21.00 & $20.00 \pm 0.8$ \\
C2ir & 18.82 & 25.00 & 21.61 & $21.81 \pm 1.8$ \\
Db & 21.29 & 11.40 & 21.30 & $18.00 \pm 3.3$ \\
Dir & 19.10 & 12.50 & 23.00 & $18.20 \pm 3.1$ \\
Eb & 23.57 & 16.92 & 22.29 & $20.93 \pm 2.0$ \\
Eir & 23.66 & 10.15 & 21.85 & $18.55 \pm 4.2$ \\
\hline
\end{tabular}

${ }^{a}$ The letter designation of the regions, the symbols attached to them mean: b is boghara and ir is irrigated soils.

Table 3: The number of algae, thousand per g of soil

\begin{tabular}{cccccc}
\hline \multirow{2}{*}{ Soil number } & \multicolumn{3}{c}{ Layer 0-2 cm } & \multicolumn{2}{c}{ Layer 0-20 cm } \\
\cline { 2 - 6 } & Spring & Summer & Autumn & Spring & Summer \\
\hline $\mathrm{A}$ & $\mathrm{N} / \mathrm{F}$ & $\mathrm{N} / \mathrm{F}$ & 21.3 & $\mathrm{~N} / \mathrm{F}$ & $\mathrm{N} / \mathrm{F}$ \\
$\mathrm{B}$ & $\mathrm{N} / \mathrm{F}$ & $\mathrm{N} / \mathrm{F}$ & 22.1 & $\mathrm{~N} / \mathrm{F}$ & $\mathrm{N} / \mathrm{F}$ \\
$\mathrm{C} 1 \mathrm{~b}$ & $\mathrm{~N} / \mathrm{F}$ & $\mathrm{N} / \mathrm{F}$ & 29.3 & $\mathrm{~N} / \mathrm{F}$ & $\mathrm{N} / \mathrm{F}$ \\
$\mathrm{C} 1 \mathrm{ir}$ & 0.19 & 0.05 & 2.83 & $\mathrm{~S}$ & $\mathrm{~S}$ \\
$\mathrm{C} 2 \mathrm{~b}$ & $\mathrm{~N} / \mathrm{F}$ & $\mathrm{N} / \mathrm{F}$ & 2.29 & $\mathrm{~N} / \mathrm{F}$ & $\mathrm{N} / \mathrm{F}$ \\
$\mathrm{C} 2$ ir & 0.21 & 0.06 & 3.05 & $\mathrm{~S}$ & $\mathrm{~S}$ \\
$\mathrm{Db}$ & $\mathrm{N} / \mathrm{F}$ & $\mathrm{N} / \mathrm{F}$ & 2.43 & $\mathrm{~N} / \mathrm{F}$ & $\mathrm{N} / \mathrm{F}$ \\
$\mathrm{Dir}$ & 0.17 & $\mathrm{~N} / \mathrm{F}$ & 2.93 & $\mathrm{~S}$ & $\mathrm{~N} / \mathrm{F}$ \\
$\mathrm{Eb}$ & $\mathrm{N} / \mathrm{F}$ & 0.15 & 33 & $\mathrm{~N} / \mathrm{F}$ & $\mathrm{N} / \mathrm{F}$ \\
Eir & 0.18 & 0.22 & 42.3 & 0.6 & 0.09 \\
\hline
\end{tabular}

${ }^{a}$ The letter designation of the regions, the symbols attached to them mean: $\mathrm{b}$ is boghara and ir is irrigated soils; N/F -not found; Ssporadic. 


\section{Soil moisture dynamics seasonally}

Seasonal differences in humidity in the studied soils (Table 2) were most pronounced in June, and least in October. At the same time, irrigated soils were distinguished by a higher moisture content than by rain-fed farming on average by $4 \%$, but in summer, these differences increased to $9 \%$.

\section{Abundance of algal flora dynamics by season}

The degree of algal flora influence on soil processes depends on their survival. Algae in a layer of $0-2 \mathrm{~cm}$ was not found in comparable conditions of non-irrigated lands winter wheat and sunflower crops (soil moisture 0-20 $\mathrm{cm} \mathrm{15-18 \% ),}$ but with irrigation, there were 98.4 thousand per $\mathrm{g}$ of soil (under sunflower, when the soil moisture content of 0-20 cm was $20.5 \%$ ) of them. Algae observations during the growing season at the studied sites showed their great liveliness (Table $3)$. In the spring, when the leaf cover of cultivated plants was small, and the soil moisture was high (Table 2), algae could be expected to develop on all soils, however, they were found in noticeable amounts only in irrigated soils in a layer of $0-2$ $\mathrm{cm}$ and in the topsoil $(0-20 \mathrm{~cm})$ sporadic. Obviously, this revealed representatives of algal sinusia, which were formed in the previous year under the influence of irrigation, because the level of moisture is one of the limiting factors for their active vegetation. The importance of moisture was indicated by the detection of algae in wet areas in spring, when soil moisture was up to $45.5 \%$ even in a layer of $0-20 \mathrm{~cm}(0.27$ thousand per $\mathrm{g}$ of soil). In summer, the number of algae reduces drastically, and in some cases, they are not detected at all. This is due to lower soil moisture during this period, as well as greater soil shading by higher plants.

The most favourable conditions for the development of algal flora have developed in the fall, when favourable conditions for soil moisture (21-24\%) and good illumination combined with the input of plant residues fresh organic

Table 4: Enzyme activity in the soil layer $0-20 \mathrm{~cm}$

\begin{tabular}{|c|c|c|c|c|c|c|c|c|c|c|c|c|}
\hline \multirow{3}{*}{ Soil number ${ }^{a}$} & \multirow{2}{*}{\multicolumn{4}{|c|}{$\begin{array}{c}\text { Dehydrogenase, mg TFF / } \\
\text { g of soil per day }\end{array}$}} & \multicolumn{4}{|c|}{ Polyphenol oxidase } & \multicolumn{4}{|c|}{ Peroxidase } \\
\hline & & & & & & mg of & 4-benzo & uinon & $10 \mathrm{~g}$ & soil for & hour & \\
\hline & SPR & SUM & AUT & $\mathbf{M N}$ & SPR & SUM & AUT & MN & SPR & SUM & AUT & MN \\
\hline A & 90.0 & 55.0 & 94.0 & 79.7 & 38 & 62 & 100 & 67 & 528 & 545 & 127 & 400 \\
\hline B & 75.0 & $\mathrm{~T}$ & 55.0 & 43.3 & 176 & 240 & 320 & 245 & 336 & 277 & 213 & 275 \\
\hline $\mathrm{C} 1 \mathrm{~b}$ & 45.0 & 23.5 & 40.5 & 36.3 & 460 & 440 & 150 & 350 & 24 & 101 & 399 & 175 \\
\hline C1ir & 98.5 & 72.5 & 61.0 & 77.3 & 470 & 464 & 215 & 383 & 42 & 102 & 343 & 162 \\
\hline $\mathrm{C} 2 \mathrm{~b}$ & 47.5 & 37.5 & 61.0 & 48.7 & 424 & 480 & 140 & 348 & 101 & 61 & 424 & 195 \\
\hline C2ir & 57.5 & 57.5 & 57.5 & 57.5 & 380 & 512 & 210 & 367 & 137 & 62 & 348 & 182 \\
\hline $\mathrm{Db}$ & 61.0 & 61 & 72.5 & 64.8 & 32 & 64 & 70 & 55 & 575 & 567 & 512 & 551 \\
\hline Dir & 86.0 & 64.5 & 100 & 83.5 & 80 & 172 & 84 & 112 & 486 & 394 & 480 & 453 \\
\hline $\mathrm{Eb}$ & 132.5 & 45.0 & 40.5 & 72.7 & 160 & 100 & 110 & 123 & 365 & 449 & 372 & 395 \\
\hline Eir & 100.0 & 72.5 & 57.5 & 76.7 & 100 & 164 & 172 & 145 & 384 & 328 & 369 & 360 \\
\hline
\end{tabular}

${ }^{\mathrm{a}}$ The letter designation of the regions, the symbols attached to them mean: $\mathrm{b}$ is boghara and ir is irrigated soils; ${ }^{\mathrm{b}} \mathrm{TFF}$ is

Trifenilformazan; T - Traces; SPR is spring, SUM is summer, AUT is autumn, MN is mean.

Table 4: Continued

\begin{tabular}{|c|c|c|c|c|c|c|c|c|}
\hline \multirow{2}{*}{ Soil number ${ }^{\mathrm{a}}$} & \multicolumn{4}{|c|}{ Phosphatase, $\mathrm{mg} \mathrm{P}_{2} \mathrm{O}_{5} / 100 \mathrm{~g}$ of soil per hour } & \multicolumn{4}{|c|}{ Urease, $\mathrm{mg} \mathrm{NO}_{3} / 100 \mathrm{~g}$ of soil per day } \\
\hline & spring & summer & autumn & mean & spring & summer & autumn & mean \\
\hline A & 1.0 & 0.5 & 1.0 & 0.8 & 44.5 & 37.8 & 25.6 & 36.0 \\
\hline B & 2.0 & 1.0 & 1.5 & 1.5 & 70.2 & 70.2 & 72.0 & 70.8 \\
\hline $\mathrm{C} 1 \mathrm{~b}$ & $\mathrm{~T}$ & $\mathrm{~T}$ & $\mathrm{~T}$ & $\mathrm{~T}$ & 44.5 & 31.7 & 36.0 & 37.4 \\
\hline Clir & $\mathrm{T}$ & $\mathrm{T}$ & $\mathrm{T}$ & $\mathrm{T}$ & 67.1 & 43.9 & 44.5 & 51.8 \\
\hline $\mathrm{C} 2 \mathrm{~b}$ & $\mathrm{~T}$ & $\mathrm{~T}$ & $\mathrm{~T}$ & $\mathrm{~T}$ & 23.8 & 43.9 & 37.8 & 35.2 \\
\hline $\mathrm{C} 2 \mathrm{ir}$ & $\mathrm{T}$ & $\mathrm{T}$ & $\mathrm{T}$ & $\mathrm{T}$ & 44.5 & 37.0 & 36. & 39.2 \\
\hline $\mathrm{Db}$ & 4.0 & 2.5 & 3.5 & 3.3 & 75.6 & 73.2 & 56.1 & 68.3 \\
\hline Dir & 5.0 & 4.0 & 4.5 & 4.5 & 85.4 & 81.7 & 56.1 & 74.4 \\
\hline $\mathrm{Eb}$ & 2.0 & 3.0 & 2.0 & 2.3 & - & 40.3 & 34.2 & 37.3 \\
\hline Eir & 3.0 & 2.0 & $\mathrm{~T}$ & 1.6 & - & 43.9 & 36.6 & 40.3 \\
\hline
\end{tabular}

${ }^{\mathrm{a}}$ The letter designation of the regions, the symbols attached to them mean: $\mathrm{b}$ is boghara and ir is irrigated soils; $\mathrm{T}-\mathrm{Traces}$. 
matter into soil. The number of algae at this time is maximum, and the differences between irrigated and nonirrigated soils are levelled.

\section{Change activity of five soil enzymes}

Soil enzymes, which are mainly of microbiological origin and are products of soil microorganism's metabolism. In the study of enzymatic activity, one cannot be limited to the definition of one of enzymes only, but it is necessary to simultaneously explore several enzymes belonging to different classes: oxidoreductases and hydrolases (Zvyagintsev, 1980). Enzymes that belong to the class of oxidoreductases (dehydrogenase, peroxidase, polyphenol oxidase), catalyze redox reactions. Such reactions are the main link in the synthesis of humic substances in soil and therefore play a certain role in the formation of structure. Hydrolases (phosphatase, urease) are a class of enzymes that catalyze the degradation catalyzing various complex organic compounds.

Analysis of data on enzyme activity (Table 4) showed that not all the enzymes clearly respond to irrigation. Of the five types of enzymes, such as dehydrogenase, polyphenol oxidase and urease reacted positively to irrigation. Soils under irrigated conditions, when compared with rain-fed farming (especially in Region D) were featuring a higher content of such enzymes as dehydrogenase (on 41\%) and polyphenol oxidase (on 34\%) spring and summer. The activity of polyphenol oxidase, an enzyme that is involved in the transformation of organic compounds of the aromatic series into components of humus, was also higher in irrigated soils than in soils without irrigation. Peroxidase activity, an enzyme that, along with polyphenol oxidases, is involved in the reactions of substances condensation during the formation of humic acid molecules, but with irrigation it is slightly less active.

Data indicate that the phosphatase activity in the studied soils is low, according the scale of Zvyagintsev (1980).

Chernozem irrigated (region D) under sunflower in all seasons showed a higher phosphatase content than on rainfed farming. Urease enrichment by the scale (Zvyagintsev, 1980 ) is assessed as low. However, irrigated soils compared with non-irrigated soils also had a higher average urease content (by 17\%), which reached up to 50\% in spring (Continued Table 4).

\section{Evaluation of the irrigated soils resistance to erosion}

Irrigated soils, as compared with non-irrigated ones, are characterized by a higher content of structural units of size $0.5-1 \mathrm{~mm}$, a lower content of water-resistant aggregates $<0.25 \mathrm{~mm}$ (an average of 1.3 times) and a better resistance to wind erosion (by value $S$ ) (Table 5). Under artificial sprinkling turbidity of carbonate chernozem in irrigated varieties was, on average, seasonal, close to the rain-fed analogies. But in the summer, when the humidity was more contrasting than in other seasons, and the advantage of irrigated soils on watering was more pronounced, the turbidity was less and the soil loss tolerance during watering was correspondingly higher than in rain-fed farming. One of the reasons that the turbidity of runoff in experiments on irrigated plots was less associated with the new physicaland-chemical and biological properties of the reclaimed land soils. The higher erosion resistance of irrigated soils, as compared to no irrigated analogues, is explained by the combined action of physicochemical processes, and also

Table 5: The results of experiments on artificial sprinkling of carbonate heavy loamy Chernozems (Moldova)

\begin{tabular}{|c|c|c|c|c|c|c|}
\hline Erosion & $\mathrm{ST}^{\mathrm{a}}$ & $\begin{array}{c}\mathrm{SA}^{\mathrm{b}} \\
\mathbf{1 - 0 . 5} \mathrm{mm}\end{array}$ & $\begin{array}{c}\text { WSA }^{\mathrm{c}} \\
<0.25 \mathrm{~mm}\end{array}$ & DEFL (\%) & $\rho_{0}(\mathrm{~g} / \mathrm{l})$ & Month \\
\hline \multirow[t]{2}{*}{ no } & $\mathrm{b}$ & 2.08 & 37.84 & 54.58 & $\begin{array}{c}6.75 \\
18.95 \\
8.30\end{array}$ & $\begin{array}{l}\text { June } \\
\text { July } \\
\text { Sept }\end{array}$ \\
\hline & ir & 35.32 & 32.84 & 56.30 & $\begin{array}{c}3.00 \\
19.49\end{array}$ & $\begin{array}{l}\text { June } \\
\text { July }\end{array}$ \\
\hline \multirow[t]{2}{*}{ weak } & $\mathrm{b}$ & 6.08 & 56.02 & 44.33 & $\begin{array}{c}6.95 \\
10.20 \\
6.91\end{array}$ & $\begin{array}{l}\text { June } \\
\text { July } \\
\text { Sept }\end{array}$ \\
\hline & ir & 50.68 & 37.40 & 56.04 & $\begin{array}{c}4.84 \\
16.65 \\
5.95\end{array}$ & $\begin{array}{l}\text { June } \\
\text { July } \\
\text { Sept }\end{array}$ \\
\hline
\end{tabular}

${ }^{a}$ ST, soil type: b is boghara and ir is irrigated soils; ${ }^{b} \mathrm{SA}$, structural aggregates; ${ }^{\mathrm{C}} \mathrm{WSA}$, water-stable aggregates. DEFL is resistance of soil structure to deflation (wind erosion). 
explained by changes in the numbers of some microbial groups (algae, fungi, aerobic cellulosedegrading microorganisms, oligonitrophiles) (Lisetskii et al., 2018).

The weakly eroded soil is less fertile due to the loss of $30 \mathrm{~cm}$ of humus horizon thickness. During artificial sprinkling, it gave comparable turbidity of runoff with noneroded soil. However, a wider range of experimental data showed that the magnitude of the absolute washability $\left(\mathrm{R}_{0}\right)$ of carbonate Chernozems varies in non-washed, weakly and medium washed options from 0.21 to 0.32 and $\mathrm{g} / \mathrm{cm}$, respectively. Irrigation of eroded soils may increase their resistance to erosion, but this requires preliminary antierosion organization of agrolandscapes.

\section{Discussion}

Studies have shown that even short-term irrigation (within 2-3 years) causes significant changes in the taxonomic and functional structure of the soil microbial cenosis (Matei et al., 2011). These changes persist also when watering is not performed due to weather conditions.

Eutrophic type bacteria, mushrooms, oligonitrophils, denitrifies and cellulose-depleting microorganisms are mostly responsive to changes caused by irrigation. Their numbers in the soil can serve, as a test indicator for the effect of irrigation, besides, it is advisable to determine the activity of dehydrogenase and urease. Enzymes in soil play an important role in metabolism, because they determine the intensity and direction of biochemical processes. The activity of dehydrogenase, an enzyme that is involved in the processes of respiration, can be considered as an indicator of the overall biological activity of soil. Indeed, an increase in dehydrogenase activity is consistent with an increase in the total number of microorganisms (algae, fungi, aerobic cellulose degrading microorganisms, oligonitrophiles) and is assessed as a positive phenomenon (Lisetskii et al., 2018). Polyphenol oxidase and peroxidase content is important role in the processes of humus formation in soils. Polyphenoloxidase catalyzes oxidized polyphenols to quinones in the presence of air oxygen. This can further result in condensation of quinones with amino acids and peptides with a humic acid primary molecule being formed (Shtina et al., 1998). The activity of polyphenol oxidase is an indicator of increased formation of primary humic acid molecules and is positive. The decrease in peroxidase activity in non-irrigated soils (Table 4) is an indicator of the tendency to the formation of humic acids less condensed, and, therefore, more labile. Our results showed that in all seasons higher phosphatase content was observed in irrigated soils compared to non-irrigated soils. It is noteworthy that when assessing the association with soil properties, phosphatase has the highest correlation coefficients with organic carbon and weighted average aggregate diameter (Sinegani et al., 2006), i.e. with factors of erosion resistance of the soil.

When considering various aspects of soil ecology and when assessing its trophic state, algae can serve as biological indicators since they are close to the higher plants by nutrition method. Moisture is an important factor, which affects the vital activities of algae. Irrigation leads to an increase in the numbers and biomass of algae and to a wider diversity and alternation of dominant forms in the population (Sukhova et al., 1989). The cenosis-forming role of soil algal flora is driven by its two features: 1) algaeinduced formation of mucous membranes and colonial mucus which are able to absorb and retain large amounts of water 2) extracellular organic secretions which include up to $20 \%$ of assimilated carbon and up to $60 \%$ of fixed nitrogen (Shtina et al., 1998). As a result, the surface of thallus and individual algae cells represents an ideal environment for the development of various bacteria finding humid conditions and food there, which contributes to soil aggregation process (Marathe, 1972; Gaydon et al., 2012). Better soil anti-erosion can be facilitated by the powerful growth of algae on soil surface (especially in the layer 0-2 $\mathrm{cm}$ ) and by their release of mucous substances which can glue soil particles.

The development of algae in soil is rather dependant on watering conditions. The obtained data on the algal sinuses in the studied soils show that irrigation has a significant impact on the development of algae. The effect of erosion resistance of soil algae was observed in aggregation of the soil particles due to mucous substances, while the interlacing threads of algae mechanically fixed those (Lisetskii et al., 2018). Vital activity of fungi, oligonitrophils and cellulose-destroying bacteria is also associated with the formation of soil structure and the increase in soil loss tolerance. Since the representatives of these groups of microorganisms react positively to irrigation, their further study is advisable to address the issues of soil loss tolerance during irrigation, as well a new world water paradigm to make the soil conditions for enzymes better (Batukaev et al., 2018).

In addition to increased non-humus coagulation during binding of soil elementary particles and growing amount of clay due to more intense soil weathering the anti-erosion resistance of irrigated soils is also caused by increasing amounts of cements of bacterial origin due to the positive role of anaerobic cellulose-degrading microorganisms, denitrifiers, and fungi, which was established earlier (Lisetskii et al., 2018). Therefore, the prospect of future studies of irrigation effects on soils may stem from 
explanations of the indicative role of enzyme activities in this diversity of processes. This will make it possible to determine an ensemble of soil indicators for the assessment and monitoring of soil protection efficiency both of irrigation technologies and of irrigation regimes in order to ensure optimal soil and hydrogeological conditions for cultivation of crops.

\section{Conclusions}

Irrigation transforms a known trans-zonal pattern for rain-fed soils of the same particle size distribution, that is reducing the number of water-resistant microaggregates and soil loss tolerance in forest-steppe and steppe zones (from typical and ordinary black soil to chestnut soils). The explanation for this phenomenon is due to the action of several key processes influenced by irrigation: 1) the increased role of humus less coagulation in the process of elementary soil particles binding; 2) the increased proportion of particles $<0.001 \mathrm{~mm}$ as products of more intensive subsurface weathering; 3 ) the increased volume of bacterial origin cements. The established increase of antierosion stability of irrigated soils can be used in practice for the arrangement of irrigation in the conditions of slope agricultural landscapes for the semiarid regions. In case of land management for hill farming (arrangement of working areas, tillage and crops along terrain contours) one can use water resources, instead of discharging excess water runoff from the water-catchment areas, in order to establish nondrain irrigation systems for higher productivity of eroded soils.

\section{Acknowledgements}

The work was done in the framework of the implementation of the base part of the state assignment of the Ministry of Education and Science of the Russian Federation for the Belgorod State National Research University on 2017-2019 years (project No. 5.4711.2017/6.7).

\section{References}

Akhtar, N., M. Naveed, M. Khalid, N. Ahmad, M. Rizwan and S. Siddique 2018. Effect of bacterial consortia on growth and yield of maize grown in Fusarium infested soil. Soil and Environment 37(1): 35-44. https://doi.org/10.25252/SE/18/872

Arinushkina, E.V. 1970. Manual for the Chemical Analysis of Soils. University Press: Moscow. Russian.

Azarbad, H., P. Constant, C. Giard-Laliberté, L.D. Bainard and E. Yergeau. 2018. Water stress history and wheat genotype modulate rhizosphere microbial response to drought. Soil Biology and Biochemistry 126: 228-236. https://doi.org/10.1016/j.soilbio.2018.08.017
Batukaev, A.A., V.P. Kalinichenko, A.E. Rykhlik and D.O. Palaeva. 2018. Intra-soil pulse continuum-discrete moistening for soil and water preservation. Advances in Engineering Research 151: 905-911.

Bulygin, S.Y. and F.N. Lisetskiy. 1992. Soil microaggregation as an index of erosion resistance. Eurasian Soil Science 24(3): 59-65.

Chen, L., C. Li, Q. Feng, (...), Y. Feng and H. Li. 2017. Shifts in soil microbial metabolic activities and community structures along a salinity gradient of irrigation water in a typical arid region of China. Science of the Total Environment 598: 64-70. https://doi.org/10.1016/j.scitotenv.2017.04.105

Dobrovol'skaya, T.G., D.G. Zvyagintsev, I.Y. Chernov, A.V. Golovchenko, G.M. Zenova, L.V. Lysak, N.A. Manucharova, O.E. Marfenina, L.M. Polyanskaya, A.L. Stepanov and M.M. Umarov. 2015. The role of microorganisms in the ecological functions of soils. Eurasian Soil Science 48(9): 959-967.

Entry, J.A., DeEtta, Mills, K. Mathee, Mathee, K., (...), R.E. Sojka and G. Narasimhan. 2008. Influence of irrigated agriculture on soil microbial diversity. Applied Soil Ecology. 40(1): 146-154.

Filip, Z., S. Kanazawa and J. Berthelin. 2000. Distribution of microorganisms, biomass ATP, and enzyme activities in organic and mineral particles of a long-term wastewater irrigated soil. Journal of Plant Nutrition and Soil Science 163(2): 143-150.

Gaydon, D.S., M.E. Probert, R.J. Buresh, H. Meinke and J. Timsina. 2012. Modelling the role of algae in rice crop nutrition and soil organic carbon maintenance. European Journal of Agronomy 39: 35-43. https://doi.org/10.1016/j.eja.2012.01.004

Goenster, S., C. Gründler, A. Buerkert and R.G. Joergensen. 2017. Soil microbial indicators across land use types in the river oasis Bulgan sum center, Western Mongolia. Ecological Indicators 76: 111-118. https://doi.org/10.1016/j.ecolind.2017.01.002

Guo, H., Z. Hu, H. Zhang, Z. Hou and W. Min. 2019. Soil microbial metabolic activity and community structure in drip-irrigated calcareous soil as affected by irrigation water salinity. Water, Air, and Soil Pollution 230(2), article No 44. https://doi.org/10.1007/s11270-019-4094-0

Guo, W., M.N. Andersen, X.-B. Qi, P. Li, Z.-Y. Li, X.-Y. Fan and Y. Zhou. 2017. Effects of reclaimed water irrigation and nitrogen fertilization on the chemical properties and microbial community of soil. Journal of Integrative Agriculture 16(3): 679-690. https://doi.org/10.1016/S2095-3119(16)61391-6

Guo, X., T. Ma, L. Chen, Y. Cui, P. Du and Y. Liao. 2014. Microbial quantities and enzyme activity in soil irrigated with sewage for different lengths of time. Ecotoxicology 
23(10): pp. 2062-2068. https://doi.org/10.1007/s10646014-1319-2

Khaziev, F.K. 1976. Enzymatic activity of soils. Nauka, Moscow.

Kuzyakov, Y. and E. Blagodatskaya. 2015. Microbial hotspots and hot moments in soil: Concept \& review. Soil Biology and Biochemistry 83: 184-199.

Li, R., R. Tao, D. Wang and G.X. Chu. 2017. Effect of mineral $\mathrm{N}$ fertilizer reduction and organic fertilizer substitution on soil biological properties and aggregate characteristics in drip-irrigated cotton field. Chinese Journal of Applied Ecology 28: 3297-3304. https://doi.org/10.13287/j.10019332.201710.029

Liang, Y.P., K.J. Li, J.P. Zhang, J.S. Sun and A.W. Duan. 2018. Extracellular enzyme activity and microbial diversity of saline-irrigated cotton field soil during the fallow period. Journal of Agro-Environment Science 37: 732-740. https://doi.org/10.11654/jaes.2017-1514

Lisetskii, F.N., A.V. Zemlyakova and A.D. Kirichenko. 2018. Variability of microbiota under diverse conditions of soil moistening. Biology Bulletin 45(4): 337-344. https://doi.org/10.1134/S106235901804009X

Lisetskii, F.N., P.V. Goleusov and O.A. Chepelev. 2013. The development of Chernozems on the Dniester-Prut interfluve in the Holocene. Eurasian Soil Science 46(5): 491-504. https://doi.org/10.1134/S1064229313050086

Lisetskii, F.N., V.I. Chernyavskikh and O.V. Degtyar. 2010. Pastures in the zone of temperate climate: trends for development, dynamics, ecological fundamentals of rational use. p.51-84. In: Pastures: Dynamics, Economics and Management. N.T. Procházka (ed.). Nova Science Publishers, Inc., New York.

Marathe, K.V. 1972. Role of some blue-green algae in soil aggregation. In: The taxonomy and Biology of Blue-green Algae. Proc. Sympos. Taxon. Boil. Blue Green Algae. Madras: Madras University, 328-331.

Matei, G.-M., S. Matei, I. Seceleanu, V. Mocanu, S. Dumitru and V. Cotet. 2011. Influence of irrigation on microbial communities and soil organic matter evolution in the Chernozem in Marculesti. Journal of Environmental Protection and Ecology 12(4): 2101-2109.

Moreno, J.L., I.F. Torres, C. García, R. López-Mondéjar and F. Bastida. 2019. Land use shapes the resistance of the soil microbial community and the $\mathrm{C}$ cycling response to drought in a semi-arid area. Science of the Total Environment 648: 1018-1030. https://doi.org/10.1016/j.scitotenv.2018.08.214

Orudzheva N.I. 2011. Microbiological characteristics of different types of irrigated soils in the subtropical zone of Azerbaijan. Eurasian Soil Science 44(11): 1241-1249.

Popelnitskaya, N.A. and V.I. Trigub. 2016. Development of irrigation in the south-west of Ukraine: a retrospective analysis. Belgorod State University Scientific Bulletin: Natural Sciences 4: 102-112.

Preece, C., E. Verbruggen, L. Liu, J.T. Weedon and J. Peñuelas. 2019. Effects of past and current drought on the composition and diversity of soil microbial communities. Soil Biology and Biochemistry 131: 2839. https://doi.org/10.1016/j.soilbio.2018.12.022

Prikhod'ko, V.E. 2008. Changes in soil properties at different levels of soil structural arrangement under the impact of irrigation. Eurasian Soil Science. Supplement 41(13): 114124. https://doi.org/10.1134/S1064229308130176

Prikhodko, V.E. and D.V. Manakhov. 2010. Soil processes at different structural levels of organization and diagnosis of their changes under irrigation. Moscow University Soil Science Bulletin 65(2): 52-60. https://doi.org/10.3103/S014768741002002X

Rietz, D.N. and R.J. Haynes. 2003. Effects of irrigationinduced salinity and sodicity on soil microbial activity. Soil Biology and Biochemistry 35(6): 845-854. https://doi.org/10.1016/S0038-0717(03)00125-1

Romashchenko, M., A. Shatkowski and O. Zhuravlev. 2016. Features of application of the Penman-Monteith method for conditions of a drip irrigation of the steppe of Ukraine (on example of grain corn). Journal of Water and Land Development 31(1): 123-127. https://doi.org/10.1515/jwld-2016-0043

Savin, I.Yu., A. Otarov, A.V. Zhogolev, M.A. Ibraeva and S. Duseikov. 2014. Long-term changes in the area of saline soils recognized by LANDSAT images in Shauldersk irrigated massive. Byulleten' Pochvennogo instituta im. V.V. Dokuchaeva 74: e38-e51.

Shtina, E.A., G.M. Zenova and N.A. Manucharova. 1998. Algological Soil Monitoring. Eurasian Soil Science 31(12): 1319-1330.

Shvebs, G.I., A.A. Svetlichnyy and S.G. Chernyy. 1988. Soil resistance to erosion in the southern Ukraine and change there in due to irrigation. Soviet Soil Science 20(4): 68-74.

Siebert, J., M. Sünnemann, H. Auge, S. Berger, S. Cesarz, M. Ciobanu, N.R. Guerrero-Ramírez and N. Eisenhauer. 2019. The effects of drought and nutrient addition on soil organisms vary across taxonomic groups but are constant across seasons. Scientific Reports 9(1), article No 639. https://doi.org/10.1038/s41598-018-36777-3

Sinegani, A.A.S., A. Hossainpour and F. Nazarizadeh. 2006. Spatial variation in soil phosphomonoesterase in irrigated and dry farmlands. Eurasian Soil Science 39(5): 507-511. https://doi.org/10.1134/S1064229306050073

Sukhova, S.N., G.M. Zenova, N.G. Zborishchuk and D.G. Zvyagintsev. 1989. Microbial populations of a southern Chernozem as an indicator of irrigation effects. Soviet Soil Science 21(5): 31-36. 
Tan, W., Y. Zhang, B. Xi, X. He, R. Gao, C. Huang ... and L. Li. 2018. Discrepant responses of the electron transfer capacity of soil humic substances to irrigations with wastewaters from different sources. Science of the Total Environment 610: 333-341.

Ullah, R., M.I. Lone, S.M. Mian, S. Ali, K.S. Ullah, A.A. Sheikh and I. Ali 2012. Impact of seasonal variations and cropping systems on soil microbial biomass and enzymatic activities in slope gradient moisture stressed soils of Punjab-Pakistan. Soil and Environment 31(1): 21-29.

Van Wyk, D.A., R. Adeleke, O.H. Rhode, C.C. Bezuidenhout and C. Mienie. 2017. Ecological guild and enzyme activities of rhizosphere soil microbial communities associated with Bt-maize cultivation under field conditions in North West Province of South Africa. Journal of Basic Microbiology 57(9): 781-792.
Volobuev, V.R. 1984. Two key solutions of the energetics of soil formation. Soviet Soil Science. 16(4): 1-8.

Zhang, Y., M. Hu, H. Liang, X. Wang, Z. Wang, Z. Jiang \& X. Li. 2016. The effects of sugar beet rinse water irrigation on the soil enzyme activities. Toxicological \& Environmental Chemistry 98(3-4):419-428.

Zvyagintsev, D.G. 1980. Methods of soil microbiology and biochemistry. MGU Publishing House, Moscow. Russian.

Zvyagintsev, D.G., I.P. Bab'eva and G.M. Zenova. 2005. Biologiya pochv (Soil Biology). Izd. MGU, Moscow. Russian. 